THE IMPACT

\section{OF ETHNIC HETEROGENEITY ON DECENTRALIZATION PERCEPTIONS IN ROMANIA}

\section{Septimiu-Rareș SZABO}

\author{
Septimiu-Rareș SZABO \\ $\mathrm{PhD}$ candidate, Doctoral School of Management, \\ Bucharest University of Economic Studies, \\ Bucharest, Romania \\ Tel.: 0040-748-481.774 \\ E-mail: septimiu.szabo@gmail.com
}

\begin{abstract}
While most research on decentralization has focused mainly on the fiscal implications, there is also a need to assess the perceptions of citizens towards the process, perceptions which are likely to differ between different ethnic, religious or cultural groups. Although Romania is one of the largest European countries, research in this area has been very limited. The aim of this paper is to provide preliminary insights into the relationship between ethnic heterogeneity and perceptions of decentralization.

Using an experimental research design, the paper examines support for decentralization in Bucharest, the mostly homogenous capital city located in Wallachia, and in Cluj-Napoca, the largest city in Transylvania with a relatively ethnically heterogeneous population. Results suggest that heterogeneous populations seem to be more sensitive to the rhetoric about decentralization.
\end{abstract}

Keywords: decentralization, ethnicity, experimental research design, Romania. 


\section{Introduction}

Over the past few decades, decentralization reforms have risen to prominence due to widespread belief that the one-size-fits-all policies imposed by central governments often fall short of improving conditions at the local level. In developing countries international organizations have often promoted it as a solution to increase the level of accountability and efficiency (Rondinelli, 1989). The varied benefits are attributed to the fact that, in contrast to standardized national policies, local governments understand better the local problems and can design policies that address local needs more quickly (Oates, 1972; Ahmad et al., 2005). In addition to attracting interest from practitioners, decentralization reforms have also generated considerable academic interest. However, the bulk of research has focused mostly on the fiscal implications. Nonetheless, as Diaz-Serrano and Rodríguez-Pose (2011) mention, the main objective of decentralization is to improve the delivery of public goods and services and respond quicker and better to citizen's needs; thus, research should also focus on analyzing the citizens' perceptions towards the reform. In this sense, ethnic heterogeneity has proven to be relevant to understanding the impacts of decentralization reforms, and several scholars have found a statistically significant relationship between the two.

Surprisingly there have been very few attempts to gauge the impact of decentralization in Romania, although this concept has been constantly discussed at the political level. This country constitutes a particularly interesting case not only because of its political importance, as the second largest European Union country in Central and Eastern Europe, but also due to its ethno-demographic distribution. While regions of Wallachia and Moldova have mostly homogenous populations, Transylvania, due to its history, is ethnically, culturally and religiously heterogeneous.

The aim of this paper is to address this important research gap by providing preliminary insight into how ethnic heterogeneity may influence citizens' perception towards decentralization using a survey experiment applied in the two largest Romanian cities which differ in terms of ethnic heterogeneity. The decision of using the experimental design is based on the fact that its results tend to resemble real world dynamics (Barabas and Jerit, 2010). The findings from this study can contribute to the continuous debate regarding the topic by demonstrating contextual factors that may catalyze or hinder decentralization.

\section{Theoretical aspects}

An increasing number of countries are decentralizing the administrative, fiscal, and political functions of the central government to lower-level governments in what has become one of the most important forms of contemporary policy reform and institutional redesign in the last several decades (Azfar et al., 1999; Ahmad et al., 2005). Decentralization can be administrative and/ or fiscal and/ or political and it can be done through deconcentration, delegation, devolution or privatization. The services that are most often decentralized are education, health, water, sanitation, public transport and infrastructure, road maintenance, fire protection, housing and social 
welfare. Macroeconomics, foreign affairs, defense and regional or national projects that generate economies of scale usually remain centralized (Ranis, 2012).

Decentralization has emerged as a solution to the problems related to excessive centralization like bureaucratic incompetence, lack of responsiveness and accountability, or ethnic conflicts (Ahmad et al., 2005; Pollitt and Bouckaert, 2011) but its success is conditional on the existence of the rule of law, transparency and accountability of government actions, citizen participation, the effectiveness of civil society or the capacity of subnational governments to deliver public goods and services (Azfar et al., 1999; Sujarwoto, 2012). Scholars have linked decentralization with increased accountability at the local level (Azfar et al., 1999; De Mello, 2000), economic growth (Iimi, 2005; Bjørnskov, Drehe and Fischer, 2008; Diaz-Serrano and Rodríguez-Pose, 2011, 2015), reduced inequalities (Ezcurra and Pascual, 2008), increased competition between jurisdictions (Tiebout, 1956; Oates, 1999; Diaz-Serrano and Meix-Llop, 2012), increased efficiency of the public service (Oates, 1999; Sujarwoto, 2012), higher responsiveness to local needs (Faguet, 2004), greater transparency (Azfar et al., 1999; McNeil and Malena, 2010), reduced corruption (Fisman and Gatti, 2002), enhanced trust in government and an increased sense of community and tolerance (Dincer, 2010; Diaz-Serrano and Rodríguez-Pose, 2011; Ligthart and Oudheusden, 2015). On the other hand there have been studies that suggested that decentralization might actually lead to a reduction of quality in service delivery (Bird, Ebel and Wallich, 1995), increased corruption (Ivanyna and Shah, 2011), enhanced interregional inequalities (Prud'Homme, 1995), reduced economic growth (Davoodi and Zou, 1998) or ethnic conflict (Arze del Granado, Martinez-Vazquez and McNab, 2012; Ranis, 2012).

\section{Decentralization and ethnic heterogeneity}

According to the classic literature, decentralization should be implemented when preferences and demands, including the ones related to public policies, are heterogeneous across jurisdictions (Tiebout, 1956; Seabright, 1996; Bardhan and Mookherjee, 2005; Wibbels, 2006). In this regard, more heterogeneous states should be inclined to decentralize but when heterogeneity is absent, a centralized provision of goods and services for all jurisdictions tends to be more efficient (Oates, 1972). Ethnic, cultural or religious groups that are characterized by a different history and which have different needs and preferences from the rest of the country can be marginalized in a centralized system. Therefore, especially in multiethnic countries, decentralization can legitimize certain groups and satisfy some of their demands for self-governance (De Mello, 2000; Tranchant, 2010) and, thus, reduce potential ethnic conflicts (Brancati, 2006; Bakke and Wibbels, 2006). Nonetheless, in Tranchant's (2010) view, this scenario is realistic only if a certain ethnic minority constitutes a majority in its jurisdiction. Otherwise, decentralization could actually encourage this minority to fight against the local majority or against the central government in order to obtain self-administration (Cornell, 2002). Even when this is not the case, some suggest that decentralization can represent a potential threat to national unity (Ranis, 2012) as heterogeneity 
may increase the potential factionalism (Azfar et al., 1999). It should also be acknowledged that local heterogeneity does not imply that different groups have their own particular interests as people do not necessarily identify themselves only with ethnicity, religion or language (Azfar et al., 1999).

From an empirical point of view, Panizza (1999) was among the first scholars that observed that decentralization is positively and significantly correlated with ethnolinguistic heterogeneity; previously, Oates (1972) found a positive but not significant relationship in his regression. Panizza's (1999) results were later confirmed by Letelier (2005), Beramendi (2007) and Canavire-Bacarreza, Martinez-Vazquez and Yedgenov (2016). On the other hand, there are a couple of papers that suggest that, while significant, the relationship is negative rather than positive (Freinkman and Plehkanov (2009) and Nana (2009) in single country analyses; Arzaghi and Henderson (2005) and Tranchant (2016) in cross-country studies). As a further acknowledgment of the relationship, many other studies have used ethnolinguistic heterogeneity as a control variable in regressions that are measuring the impact of decentralization (Canavire-Bacarreza, Martinez-Vazquez and Yedgenov, 2016).

\section{Decentralization in Romania}

In Romania, the seventh largest country in terms of population in the European Union, ethnic Romanians make up almost $90 \%$ of the population. The largest ethnic minorities are Hungarians and Romani people, who make up 6.5\% respectively 3.3\% of the population. The country was ranked $86^{\text {th }}$ out of 159 analyzed countries in Alesina's et al. (2003) cultural diversity index, and it was ranked even lower on ethnic fractionalization (161 out of 215), linguistic fractionalization (137 out of 215) or religious fractionalization (162 out of 215) indexes. Fearon (2003) also considers it to have a relatively low ethnic fractionalization score and ranked it $112^{\text {th }}$ out of 159 analyzed countries. Nonetheless, there are large variations between the regions. While Wallachia and Moldova are homogenous, Transylvania has been always ethnically-diverse as, in addition to the ethnic Romanians, it historically had a significant number of Hungarians, Germans and Jews. After the Second World War, the Hungarian minority enjoyed a certain degree of autonomy but after 1968 the communist regime started pursuing a nationalistic policy and tried to homogenize the heterogeneous territories (Chen, 2003).

After the 1989 revolution, ethnic nationalism was constantly used in the public discourse especially in relation to the Hungarian minority (Linz and Stepan, 1996). Thus, in the early 1990s and especially after the ethnic clashes of Târgu Mureș which left six people dead and 300 injured in 1990, proposing any form of devolution has been characterized as anti-constitutional behavior and was banned from the public discourse for several years. Furthermore, the increased activism of the politically organized Hungarian minority, which requested self-governance and some form of territorial autonomy, strengthened fears of unintended consequences of decentralization (Horváth and Scacco, 2001; Csergo, 2007). In 2001 a group of Hungarian and 
Romanian intellectuals from Cluj-Napoca, which considered Transylvania a different region from the rest of the country in terms of historical cultural heritage, ethnic composition and even electoral behavior (Molnar, 2000), requested the central government to start decentralizing as this might improve the Romanian-Hungarian interethnic relations in the region. The central government on the other hand saw decentralization as a matter of national security and implemented only small and incremental reforms (Csergo, 2007).

While the first post-communist Constitution in 1991 laid out the principles of local autonomy, it ruled out any political decentralization. The 2003 revised Constitution introduced the concept of deconcentration and allowed ethnic minorities to use their own language in local administration in areas where they are a majority. Subsequent governments have decentralized, to a certain degree, various services like land management, local road infrastructure and public transportation, local cultural institutions, local public health units, territorial development and urban planning, water supply, sewage, public lighting, social assistance and protection for children, elders and victims of gender-based violence. There are also shared competences between central and local governments in areas like heating provision, social housing, primary and secondary education, public safety, social welfare, emergency situations, medical and social assistance services or population records. All other services are either handled centrally or deconcentrated under the supervision of the prefect which is the central government's representative (Profiroiu, Profiroiu and Szabo, 2017).

The research in the area is scarce. In a study from 2006, Profiroiu and Profiroiu suggest that most local elected officials tend to favor decentralization. In smaller communities, however, there was a more negative opinion. In a survey undertaken in 2008, patients did not see decentralization as a solution for the problems of the Romanian health system (Popa, 2011). Another study suggested that ethnic Romanians were concerned about devolving authority to the subnational level (Bako et al., 2006). A public survey administered by the CCSCC (Centrul de Cercetări și Studii Calitative și Cantitative) in 2013 suggested that almost 50\% supported decentralization and most agreed that service delivery would be better administered at the local level. On the other hand, $85 \%$ believed that decentralization might lead to further empowerment of the local leaders, $75 \%$ considered that it would increase corruption and a majority thought that decentralization could increase regional inequalities.

As such, in light of the arguments outlined above the study proposes the following hypothesis: 'citizens from ethnically heterogeneous regions are more sensitive to rhetoric about decentralization'.

\section{Method and data}

The study compares the two largest cities in Romania, which are quite different in terms of ethnic heterogeneity. Bucharest (the capital) is located in historical Walachia and is the sixth largest city in the EU with a mostly homogenous population of around 2 million. The second largest city of Romania, Cluj-Napoca, is located in 
historical Transylvania and has a population of roughly 400,000 out of which 50,000 are ethnic Hungarians. The study uses cities instead of counties because, as Sujarwoto (2012) mentioned, the locus of decentralization reform is located at the local government level which is below the provincial administration. Bucharest and Cluj-Napoca are also relevant places to do the research since, as mentioned in the previous chapter, the debate about decentralization in Romania was mostly discussed in these two cities and most often, at opposite ends.

Using snowball sampling, electronic invitations to participate in the survey were submitted to inhabitants in each city. While this method has certain disadvantages like community bias, lack of control and anchoring, Noy (2008) suggests that this widely used technique can generate a unique, emergent, political and interactional type of social knowledge. 299 responses in Bucharest and 252 responses in Cluj-Napoca were collected in October 2016. After removing those that were incomplete and those filled out in less than two minutes, while making sure that the completed surveys matched the characteristics of the target samples, 208 useful responses in Bucharest $(0.01 \%$ of the population) and 153 in Cluj-Napoca ( $0.04 \%$ of the population) were retained.

The two samples are similar in terms of gender, education, professional status and income but rather different in terms of ethnicity. While in Bucharest $97.60 \%$ of the respondents are Romanian, in Cluj-Napoca, $11.80 \%$ are of a different ethnicity. These figures reflect to a certain degree the current demographics of the two cities since Romanians make $96.6 \%$ of the population in Bucharest while in Cluj-Napoca $18.5 \%$ are of a different ethnicity. The characteristics of the sample can be found in Table 1.

The study uses a scenario-based survey experiment that follows a 2 X 2 factorial, between-subjects design. Due to their unmatched capacity of establishing causality, experiments have been used extensively since the late 1960s to investigate a wide range of issues in social sciences as they offer accurate insights into trends experienced in real life (Mutz, 2011). In a study undertaken in 2006, Druckman et al. found 57 experimental studies, including survey experiments, published in the first $100 \mathrm{vol}-$ umes of the American Political Science Review and suggested that their number had been growing rapidly. The decision to use this research design is based on the assumption that the treatments and the randomization can point towards the direction, if not the rough magnitude, of the effects that might be expected to occur in the real world (Gaines, Kuklinski and Quirk, 2007). In addition, randomized Internet survey experiments that analyze how the presentation of information alters beliefs are seen as a very valuable tool for studying public opinion (Lavine, 2002; Barabas and Jerit, 2010).

Despite their great potential, there have been very few attempts to analyze the phenomenon of decentralization using the experimental design, although it is a wellknown fact that standard empirical research on the effects of decentralization is influenced by endogeneity and omitted variables bias and many scholars have suggested expanding the research methodologies (Asatryan and Feld, 2015). Guth, Levati and 
Table 1: Samples statistics

\begin{tabular}{|c|c|c|c|}
\hline & & Bucharest & Cluj-Napoca \\
\hline \multirow{4}{*}{ Number of responses } & Total Responses & 299 & 252 \\
\hline & Used Responses & 208 & 153 \\
\hline & Treatment Group 1/3 & 106 & 80 \\
\hline & Treatment Group 2/4 & 102 & 73 \\
\hline \multirow{2}{*}{ Gender } & Female & $54.30 \%$ & $59.50 \%$ \\
\hline & Male & $45.70 \%$ & $40.50 \%$ \\
\hline \multirow{5}{*}{ Age } & $19-24$ & $20.67 \%$ & $27.50 \%$ \\
\hline & $25-40$ & $67.78 \%$ & $64.10 \%$ \\
\hline & $41-50$ & $7.21 \%$ & $3.90 \%$ \\
\hline & $51-60$ & $3.36 \%$ & $2.00 \%$ \\
\hline & over 61 & $1.00 \%$ & $1.30 \%$ \\
\hline \multirow{4}{*}{ Ethnicity } & Romanian & $97.60 \%$ & $88.20 \%$ \\
\hline & Hungarian & $0.50 \%$ & $9.20 \%$ \\
\hline & Romani & $1.00 \%$ & $0.70 \%$ \\
\hline & Other & $1.00 \%$ & $2.00 \%$ \\
\hline \multirow{5}{*}{ Last Degree } & No Degree & $0.48 \%$ & $0.70 \%$ \\
\hline & Middle School Degree & $0.50 \%$ & $0.70 \%$ \\
\hline & Baccalaureate & $17.30 \%$ & $26.80 \%$ \\
\hline & Bachelor Degree & $21.15 \%$ & $28.80 \%$ \\
\hline & Graduate Degree & $60.56 \%$ & $43.10 \%$ \\
\hline \multirow{5}{*}{ Professional Status } & Employed & $78.36 \%$ & $69.20 \%$ \\
\hline & Student & $16.36 \%$ & $26.10 \%$ \\
\hline & Unemployed & $0.50 \%$ & $0.70 \%$ \\
\hline & Retired & $0.00 \%$ & $0.70 \%$ \\
\hline & Other status & $4.80 \%$ & $3.30 \%$ \\
\hline \multirow{7}{*}{ Monthly net income } & $<925$ lei & $9.13 \%$ & $14.40 \%$ \\
\hline & $925-2,000$ lei & $8.65 \%$ & $24.20 \%$ \\
\hline & $2,000-4,500$ lei & $30.28 \%$ & $30.70 \%$ \\
\hline & $4,500-9,000$ lei & $24.51 \%$ & $13.10 \%$ \\
\hline & $9,000-15,000$ lei & $10.09 \%$ & $3.30 \%$ \\
\hline & More than 15,000 lei & $1.44 \%$ & $1.40 \%$ \\
\hline & Don't want to answer & $15.86 \%$ & $13.10 \%$ \\
\hline
\end{tabular}

Source: Author's compilation

Sausgruber (2005) use an experiment in Germany to show that centralization induces lower tax morale and less efficient outcomes. Rosenblatt et al. (2015) use an experiment in Uruguay to show that citizens from more decentralized cities have more positive attitudes towards politics than those from the centralized ones. Similarly, while not necessarily related to decentralization, there have been several experiments related to tax compliance and willingness to pay taxes, conducted in the USA and in Europe.

Participants were invited via email through the Qualtrics computer software to participate in the study where they could follow a link leading to the stimuli and 
subsequent survey. At the beginning of the experiment, subjects in both cities were provided with instructions and a brief description of the experiment. After agreeing to participate, subjects were randomly assigned to one of the two treatment groups where they were provided with a different fictitious scenario within their city. Both vignettes present a press release from a candidate running for mayor in which he advocates either for more centralization or for more decentralization. According to the results of the chi-square test for homogeneity ( $p>0.05$ in all tests in both cities), the randomly assigned respondents in sample are not significantly different in terms of age, gender, education, professional status, income or ethnicity. Thus, it can be assumed that the difference in responses is influenced by the manipulation and, due to randomization, any difference in answers can be interpreted as an effect of the treatment (Blom-Hansen, Morton and Serritzlew, 2015).

The treatments are in line with previous survey experiments and are reflective of the real world. After reading one of the two vignettes, all subjects were asked to respond to the same questions. They were asked to what extent they agreed that 12 public services should be controlled and financed by the local governments within their city and not by the central government. While the list of public services provided at the local level is much longer, these particular 12 were considered to be the most representative as they combined centralized services (higher education, emergency services, judicial system, building of social housing), decentralized services (local public transport, street administration, parks and recreation) and services with shared competence between the central and the local level (primary and secondary education, hospitals and medical care, police, social assistance and child protection, museums and public libraries).

All items were measured using a 7-point Likert-type scale where a score of 1 corresponds to 'strongly agree', and a score of 7 corresponds to 'strongly disagree'. Before launching the main experiment, a pilot study was run on a sample of 16 persons ( 4 in each treatment group). Initially the survey included two questions related to support for centralization and support for decentralization. Based on the feedback obtained, the first question was dropped from the experiment. No pre-testing was undertaken since this could have primed respondent and biased the causal estimates. The vignettes and the question survey are presented in Annex 1.

For the aggregated measure of support for decentralization, instead of averaging responses to the 12 services used to measure each of the constructs, the analysis constructed the composite measures using principal component factoring (DeVellis, 2016). This method is more accurate for measuring latent constructs as it weights the contribution of each item to the latent construct according to the degree of commonality it shares with the said construct (Porumbescu, 2017). Each of the latent constructs used in this study explained variance from $17 \%$ to $39 \%$ in Bucharest and 10\% to $34 \%$ in Cluj-Napoca; details are provided in Table 2. 
Table 2: Total variance explained in the two samples

\begin{tabular}{ccccccc}
\hline \multirow{2}{*}{ Component } & \multicolumn{3}{c}{ Initial Eigenvalues - Bucharest } & \multicolumn{3}{c}{ Initial Eigenvalues - Cluj-Napoca } \\
\cline { 2 - 6 } & Total & \% of Variance & Cumulative \% & Total & \% of Variance & Cumulative \% \\
\hline 1 & 4.646 & 38.714 & 38.714 & 4.161 & 34.672 & 34.672 \\
2 & 2.111 & 17.591 & 56.305 & 2.244 & 18.700 & 53.371 \\
3 & .946 & 7.880 & 64.185 & 1.240 & 10.336 & 63.708 \\
\hline 4 & .858 & 7.149 & 71.333 & .950 & 7.921 & 71.628 \\
\hline 5 & .767 & 6.394 & 77.727 & .730 & 6.081 & 77.710 \\
6 & .605 & 5.044 & 82.771 & .568 & 4.731 & 82.440 \\
7 & .525 & 4.374 & 87.145 & .482 & 4.020 & 86.461 \\
8 & .437 & 3.641 & 90.786 & .427 & 3.560 & 90.020 \\
\hline 9 & .361 & 3.011 & 93.797 & .337 & 2.807 & 92.827 \\
\hline 10 & .285 & 2.377 & 96.174 & .314 & 2.616 & 95.443 \\
\hline 11 & .257 & 2.145 & 98.318 & .285 & 2.379 & 97.821 \\
\hline 12 & .202 & 1.682 & 100.000 & .261 & 2.179 & 100.000 \\
\hline
\end{tabular}

Source: Author's compilation

\section{Research results}

\subsection{Main findings}

The mean values of the four treatment groups are presented in Table 3 while the detailed mean values of all the 12 services are shown in Table 4 .

A one-way analysis of variance was used to assess whether there were significant differences between the two treatment groups in each city. The results reveal that participants in Bucharest seem to not have been significantly influenced by the manipulation since there is no significant difference in responses between the two treatment groups as $F(1,206)=1.644, p=.201$. This suggests that Bucharest participants' attitudes toward questions of decentralization or centralization of public service provision are not very sensitive to political rhetoric on the issue. However, contrary to the expectations,

Table 3: Mean values of treatment groups in each sample

\begin{tabular}{|c|c|c|c|c|c|c|c|c|}
\hline & \multirow{2}{*}{$\mathrm{N}$} & \multirow{2}{*}{ Mean } & \multirow{2}{*}{$\begin{array}{c}\text { Std. } \\
\text { Deviation }\end{array}$} & \multirow{2}{*}{$\begin{array}{l}\text { Std. } \\
\text { Error }\end{array}$} & \multicolumn{2}{|c|}{$\begin{array}{l}95 \% \text { Confidence } \\
\text { Interval for Mean }\end{array}$} & \multirow{2}{*}{ Min } & \multirow{2}{*}{ Max } \\
\hline & & & & & $\begin{array}{l}\text { Lower } \\
\text { Bound }\end{array}$ & $\begin{array}{l}\text { Upper } \\
\text { Bound }\end{array}$ & & \\
\hline \multicolumn{9}{|c|}{ Bucharest Sample } \\
\hline Centralization & 106 & 2.8711 & .96726 & .09395 & 2.6848 & 3.0574 & 1.00 & 5.08 \\
\hline Decentralization & 102 & 3.0596 & 1.14887 & .11376 & 2.8340 & 3.2853 & 1.00 & 7.00 \\
\hline Total & 208 & 2.9635 & 1.06185 & .07363 & 2.8184 & 3.1087 & 1.00 & 7.00 \\
\hline \multicolumn{9}{|c|}{ Cluj-Napoca Sample } \\
\hline Centralization & 80 & 2.7563 & 1.01247 & .11320 & 2.5309 & 2.9816 & 1.00 & 6.00 \\
\hline Decentralization & 73 & 2.5400 & 0.86837 & .10164 & 2.3373 & 2.7426 & 1.00 & 5.67 \\
\hline Total & 153 & 2.6531 & 0.94959 & .07677 & 2.5014 & 2.8047 & 1.00 & 6.00 \\
\hline
\end{tabular}

Source: Author's compilation 
Table 4: Mean values of the services analyzed in each treatment group

\begin{tabular}{lcccc}
\hline & \multicolumn{3}{c}{ Bucharest } & \multicolumn{2}{c}{ Cluj-Napoca } \\
\cline { 2 - 5 } & $\begin{array}{c}\text { Centralization } \\
\text { manipulation }\end{array}$ & $\begin{array}{c}\text { Decentralization } \\
\text { manipulation }\end{array}$ & $\begin{array}{c}\text { Centralization } \\
\text { manipulation }\end{array}$ & $\begin{array}{c}\text { Decentralization } \\
\text { manipulation }\end{array}$ \\
\hline Schools & 3.37 & 3.63 & 3.25 & 2.77 \\
Universities & 4.29 & 4.21 & 4.03 & 3.16 \\
Building of social housing & 2.10 & 2.41 & 2.43 & 2.00 \\
Social and child protection & 2.44 & 2.94 & 2.56 & 2.53 \\
Public transport & 1.66 & 2.00 & 1.90 & 1.60 \\
Street administration & 1.74 & 1.88 & 1.80 & 1.77 \\
Hospitals and medical care & 3.32 & 3.70 & 2.86 & 2.81 \\
Emergency situations & 3.06 & 3.04 & 2.74 & 2.71 \\
Police & 3.70 & 3.64 & 3.16 & 3.27 \\
Judicial system & 4.86 & 5.10 & 4.26 & 4.23 \\
Museum and libraries & 2.30 & 2.41 & 2.23 & 2.01 \\
Parks and recreation & 1.61 & 1.76 & 1.86 & 1.60 \\
\hline
\end{tabular}

Source: Author's compilation

for nine public services respondents that received the centralization manipulation seem to support greater decentralization than those that received the decentralization manipulation.

In Cluj-Napoca, on the other hand, there is a significant difference between the treatment groups as $\mathrm{F}(1,151)=4.73, p=0.03$. In other words, it appears that the attitudes of participants from this city are more sensitive to decentralization rhetoric than to centralization rhetoric. Moreover, there is descriptive evidence for all 12 services apart from police that participants that received the decentralization manipulation are much more inclined to support the reform than those that received the centralization manipulation. Furthermore, the Cluj-Napoca sample is much more inclined to support decentralization compared to Bucharest. Apart from parks and recreation, the respondents in Cluj-Napoca appear stronger in their support of decentralization for all the proposed services with significant differences in areas like education, medical care and law enforcement.

\subsection{Discussion}

Taking into account the differences between the two samples, we can conclude that the proposed hypothesis is supported. People from Cluj-Napoca are much more sensitive to rhetoric about decentralization compared to those from Bucharest and they are also much more inclined to support the reform. While this difference is not really surprising, taking into account the different history of the two cities, the author expected to see much more interest for decentralization in Bucharest for a number of reasons. The capital city is by far the most developed city in Romania contributing with $18 \%$ to the national GDP, while Cluj County, which incorporates six additional cities and towns and 75 additional communes, contributes with only $4 \%$. Furthermore, the GDP per capita in Bucharest is twice as high as in Cluj-Napoca $(19,700$ EUR 
versus 9,400 EUR in 2014) and according to the National Commission for Prognosis (2016) this difference will continue at least until 2020 as both GDP levels are expected to grow at the same pace. Bucharest is also an economy powerhouse at the European level having a GDP per capita of $130 \%$ of the European Union average. Combined with the fact that it is the sixth largest city in the European Union, it could have been expected that people living in Bucharest to be more interested in devolving power to the local administration as several other European capital cities like London or Brussels have requested.

Another reason for this reluctance to embrace decentralization is related to the corruption problems of the local administration in Bucharest since two former mayors have already been investigated for corruption. Taking into account the CCSCC survey results from 2013, when a large majority believed that decentralization leads to increased corruption and local capture, it might be assumed that people from $\mathrm{Bu}-$ charest might be skeptical to empower the local administration even more. This is also portrayed by low turnouts during the local elections (25\% in 2005, 30\% in 2008, and $33 \%$ in 2016). Furthermore, some citizens might not consider being fully represented by the local government due to the first-past-the-post electoral system through which the current mayor won the election by gaining the support of only $13 \%$ of the entire Bucharest population that is eligible to vote.

In Cluj-Napoca, on the other hand, there has been a continuous battle for devolution since the Middle-Ages when the Romanian majority continually requested more rights from the Hungarian or Habsburg crowns. Therefore, it is not surprising that its residents are more sensitive towards this reform as decentralization, in this context, may be of greater cultural significance. It should be mentioned, however, that the political tendency in Cluj-Napoca is to vote for parties that are right-of-center. Leftof-center parties, that have been more inclined to promote decentralization in the past decade, have never won the local elections since the 1989 revolution. This is related to the fact that people might perceive the major left-of-center party in Romania to be somehow connected with the communist party, which adopted an excessive centralization policy.

Since the results are not statistically representative for the whole country, the current study does not recommend more or less decentralization. Nonetheless, the results might suggest that an extended prolongation of the status quo might involve political costs for the subsequent governments, at least in certain regions of the county. In this regard, a possible hypothetical solution would be the implementation of the Spanish model which uses an asymmetric decentralization system where some regions are more autonomous than others. Nonetheless, the application of this framework in Romania would be difficult to implement using the current administrative divisions that lack a regional layer. Another hypothetical solution would be to devolve more authority only to certain large and prosperous cities, while not implementing a full decentralization reform. 
Regardless of the way forward, the results of this study suggest that practitioners need to find a way to satisfy various heterogeneous preferences as a one-size-fits-all approach cannot be a viable solution on the long term.

\subsection{Limitations of the study}

The geographical distribution of the analysis, certain particularities seen within the two samples and certain limitations related to the use of the research design limit the results of the analysis. Although the results are assumed to be representative for a significant part of the country's population, perceptions in the regions of Moldova, Oltenia or Székely Land might be, and probably are, different or significantly different from those presented in the current study. Although the samples represent a diverse pool of participants, the author acknowledges that it uses a non-probability voluntary sample with strong internal validity but low external validity making it not statistically representative for the whole country. Nonetheless, as mentioned by Remler and Van Ryzin (2010), most behavioral studies using experiments rely on voluntary samples and the aim of the experimental design is obtaining internal rather than external validity. In addition, as mentioned by Mutz (2011), there is no empirical proof for championing one research setting over another for purposes of external validity.

A further limitation is the reduced response rate from people that are over 51 years old, are unemployed or are retired and the significantly large participation of respondents with higher education. While both cities are relatively younger, more educated and with a larger workforce than the rest of the country, the author acknowledges that is more representative for working people or students under 50 that obtained or are pursuing an academic degree. Nonetheless, these are inherent limitations based on the fact that the surveys were administered online using a computer software.

Another limitation of using the survey experiment is the fact that people may not give honest responses, wish to appear consistent with previous answers or to appear to comply with the status-quo of the society (Wenzel, 2005). In addition, it is assumed that the manipulation of one feature from the vignette will generally change respondents' beliefs about other features of the scenario as they are using their knowledge from real life (Guth, Levati and Sausgruber, 2005).

\section{Conclusions}

The aim of this paper was to provide preliminary insights into the relationship between ethnic heterogeneity and perceptions of decentralization. Results suggest that there is a relation as people from Cluj-Napoca are much more sensitive to the rhetoric about decentralization compared to those from Bucharest. They are also much more inclined towards the reform although in the past 25 years decentralization was implemented with little planning or analysis and without increasing the capacity of the local governments (Profiroiu, Profiroiu and Szabo, 2017). As mentioned by Profiroiu and Szabo (2016), there is no unanimously agreed solution on how decentralization should be implemented, especially in developing countries. However, Roma- 
nia should not fall into trap of transposing a successful practice from the developed countries in the West and should frame it in accordance with its complex institutional realities.

If Romanian decision-makers want to adopt some good practices in terms of decentralization, they might look into the case of Poland, a country with a similar history that has strongly empowered subnational governments in the past 25 years (Szabo, 2015). Regardless of the adopted solution, the central government needs to start looking more into the separation of powers between the different layers of government in order to find a right balance that, on one hand respects the principle of subsidiarity, and on the other satisfies to some degree the needs and preferences of all ethnic, linguistic and religious groups in the country. Since further studies on this topic in Romania are much needed, scholars should replicate the analysis in other regions of Romania and try to include the whole structure of the population.

\section{References:}

1. Ahmad, J.K., Devarajan, S., Khemani, S. and Shah, S., 'Decentralization and Service Delivery', 2005, World Bank Policy Research Working Paper No. 3603, [Online] available at https://ssrn.com/abstract=753505, accessed on April 28, 2016.

2. Alesina, A., Devleeschauwer, A., Easterly, W., Kurlat, S. and Wacziarg, R., 'Fractionalization', 2003, Journal of Economic Growth, vol. 8, no. 2, pp.155-194.

3. Arzaghi, M.J. and Henderson, J.V., 'Why Countries A re Fiscally Decentralizing', 2005, Journal of Public Economics, vol. 89, no. 7, pp. 1157-1189.

4. Arze del Granado, F.J., Martinez-Vazquez, J. and McNab, R.M., 'Decentralized Governance and Preferences for Public Goods', 2012, MPRA Paper no. 42459, [Online] available at https://mpra.ub.uni-muenchen.de/42459, accessed on October 28, 2016.

5. Asatryan, Z. and Feld, L.P., 'Revisiting the Link between Growth and Federalism: A Bayesian Model Averaging Approach', 2015, Journal of Comparative Economics, vol. 43, no. 3, pp. 772-781.

6. Azfar, O., Kahkonen, S., Lanyi, A., Meagher, P. and Rutherford, D., 'Decentralization, Governance and Public Services: The Impact of Institutional Arrangements. A Review of the Literature', 1999, [Online] available at http://siteresources.worldbank. org/INTINDONESIA/Resources/Decentralization/Lit_Review_IRIS.pdf, accessed on October 28, 2016.

7. Bakke, K.M. and Wibbels, E., 'Diversity, Disparity, and Civil Conflict in Federal States', 2006, World Politics, vol. 59, no. 1, pp. 1-50.

8. Bako, R., Noica, R., Stan, R. and Pippidi, M.A., 'Regions, Minorities and European Integration: A Case Study on Hungarians in Romania', 2006, [Online] available at www. eliamep.gr/old/eliamep/files/Romania_Revised_\%20alina.pdf, accessed on October 28, 2016.

9. Barabas, J. and Jerit, J., 'Are Survey Experiments Externally Valid?', 2010, American Political Science Review, vol. 104, no. 2, pp. 226-242.

10. Bardhan, P. and Mookherjee, D., 'Decentralizing Antipoverty Program Delivery in Developing Countries', 2005, Journal of Public Economics, vol. 89, no. 4, pp. 675-704. 
11. Beramendi, P., 'Inequality and the Territorial Fragmentation of Solidarity', 2007, International Organization, vol. 61, no. 4, pp. 783-820.

12. Bird, R.M., Ebel, R.D. and Wallich, C.I. (eds.), Decentralization of the Socialist State: Intergovernmental Finance in Transition Economies, Washington: World Bank, 1995.

13. Bjørnskov, C., Drehe, A. and Fischer, J.A.V., 'On Decentralization and Life Satisfaction', 2008, Economics Letters, vol. 99, no. 1, pp. 147-151.

14. Blom-Hansen, J., Morton, R. and Serritzlew, S., 'Experiments in Public Management Research', 2015, International Public Management Journal, vol. 18, no. 2, pp. 151-170.

15. Brancati, D., 'Decentralization: Fueling the Fire or Dampening the Flames of Ethnic Conflict and Secessionism?', 2006, International Organization, vol. 60, no. 3, pp. 651-685.

16. Canavire-Bacarreza, G., Martinez-Vazquez, J. and Yedgenov, B., 'Reexamining the Determinants of Fiscal Decentralization: What Is the Role of Geography?', 2016, Journal of Economic Geography, [Online] available at https://academic.oup.com/joeg/article/ doi/10.1093/jeg/lbw032/2742063/Reexamining-the-determinants-of-fiscal, accessed on October 28, 2016.

17. Centrul de Cercetări și Studii Cantitative și Calitative, 'Sondaj de opinie - Procesul de descentralizare, Noiembrie 2013 (Survey - The decentralization process, November 2013)' , 2013 [Online] available at www.ccscc.ro/images/sondaje/Sondaj\%20CCSCC $\% 20$ nov\%202013.pdf, accessed on October 28, 2016.

18. Chen, C., 'The Roots of Illiberal Nationalism in Romania: A Historical Institutionalist Analysis of the Leninist Legacy', 2003, East European Politics E Societies, vol. 17, no. 2, pp. 166-201.

19. Comisia Națională de Prognoză (National Prognosis Commission), 'Proiecţia principalilor indicatori economico - sociali în profil teritorial până în 2019 (The Prognosis of the Main Socio-economic Indicators on Geographical Bases until 2019)', 2016, [Online] available at www.cnp.ro/user/repository/prognoze/prognoza_profil_teritorial_ mai_2016.pdf, accessed on October 28, 2016.

20. Cornell, S.E., 'Autonomy as a Source of Conflict: Caucasian Conflicts in Theoretical Perspective', 2002, World Politics, vol. 54, no. 2, pp. 245-276.

21. Csergo, Z., Talk of the Nation. Language and Conflict in Romania and Slovakia, Ithaca, NY: Cornell University Press, 2007.

22. Davoodi, H. and Zou, H.F., 'Fiscal Decentralization and Economic Growth: A Cross-country Study', 1998, Journal of Urban Economics, vol. 43, no. 2, pp. 244-257.

23. De Mello, L.R., 'Fiscal Decentralization and Intergovernmental Fiscal Relations: A Cross-country Analysis', 2000, World Development, vol. 28, no. 2, pp. 365-380.

24. DeVellis, R.F., Scale Development. Theory and Applications, New York: Sage, 2016.

25. Diaz-Serrano, L. and Meix-Llop, E., 'Do Fiscal and Political Decentralization Raise Students' Performance? A Cross-Country Analysis', 2012, IZA Discussion Paper No. 672, [Online] available at https://papers.ssrn.com/sol3/papers.cfm?abstract_id=2114902, accessed on October 28, 2016.

26. Diaz-Serrano, L. and Rodríguez-Pose, A., 'Decentralization and the Welfare State: What Do Citizens Perceive?', 2015, Social Indicators Research, vol. 120, no. 2, pp. 411-435.

27. Diaz-Serrano, L. and Rodríguez-Pose, A., 'Decentralization, Happiness, and the Perception of Institutions', 2011, CEPR Discussion Papers No. 8356, [Online] available at 
https://papers.ssrn.com/sol3/papers2.cfm?abstract_id=1830974, accessed on October $28,2016$.

28. Dincer, O., 'Fiscal Decentralization and Trust', 2010, Public Finance Review, vol. 38, no. 2, pp. 178-192.

29. Druckman, J.N., Green, D.P., Kuklinski, J.H. and Lupia, A., 'The Growth and Development of Experimental Research in Political Science', 2006, American Political Science Review, vol. 100, no. 4, pp. 627-635.

30. Ezcurra, R. and Pascual, P., 'Fiscal Decentralization and Regional Disparities: Evidence from Several European Union Countries', 2008, Environment and Planning A, vol. 40, no. 5, pp. 1185-1201.

31. Faguet, J.P., 'Does Decentralization Increase Government Responsiveness to Local Needs?: Evidence from Bolivia', 2004, Journal of Public Economics, vol. 88, no. 3-4, pp. 867-893.

32. Fearon, J.D., 'Ethnic and Cultural Diversity by Country', 2003, Journal of Economic Growth, vol. 8, no. 2, pp. 195-222.

33. Fisman, R. and Gatti, R., 'Decentralization and Corruption: Evidence across Countries', 2002, Journal of Public Economics, vol. 83, no. 3, pp. 325-345.

34. Freinkman, L. and Plekhanov, A., 'Fiscal Decentralization in Rentier Regions: Evidence from Russia', 2009, World Development, vol. 37, no. 2, pp. 503-512.

35. Gaines, B.J., Kuklinski, J.H. and Quirk, P.J., 'The Logic of the Survey Experiment Reexamined', 2007, Political Analysis, vol. 15, no. 1, pp. 1-20.

36. Güth, W., Levati, V. and Sausgruber, R., 'Tax Morale and (De-)Centralization: An Experimental Study', 2005, Public Choice, vol. 125, no. 1-2, pp. 171-188.

37. Horváth, I. and Scacco, A., 'From the Unitary to the Pluralistic: Fine Tuning Minority Policy in Romania', in Biro, A.M. and Kovacs, P. (eds.), Diversity in Action: Local Public Management of Multi Ethnic Communities in Central and Eastern Europe, Budapest: OSF, 2001, pp. 241-273.

38. Iimi, A., 'Decentralization and Economic Growth Revisited: An Empirical Note', 2005, Journal of Urban Economics, vol. 57, no. 3, pp. 449-461.

39. Ivanyna, M. and Shah, A., 'Decentralization and Corruption: New Cross-country Evidence', 2011, Environment and Planning C: Government and Policy, vol. 29, no. 2, pp. 344-362.

40. Lavine, H., 'On-line versus Memory-based Process Models of Political Evaluation', in Monroe, K.R. (ed.), Political Psychology, Mahwah, NJ: Psychology Press, 2002, pp. 225-274.

41. Letelier, L.S., 'Explaining Fiscal Decentralization', 2005, Public Finance Review, vol. 33, no. 2, pp. 155-183.

42. Ligthart, J.E. and van Oudheusden, P., 'In Government We Trust: The Role of Fiscal Decentralization', 2015, European Journal of Political Economy, vol. 37, pp. 116-128.

43. Linz, J.J. and Stepan, A., Problems of Democratic Transition and Consolidation: Southern Europe, South America, and Post-communist Europe, Baltimore: JHU Press, 1996.

44. McNeil, M. and Malena, C., Demanding Good Governance: Lessons from Social Accountability Initiatives in Africa, Washington: World Bank, 2010.

45. Molnar, M., 'Poverty Measurement and Income Support in Romania', in Hutton, S. and Redmond, G. (eds.), Poverty in Transition Economies, London: Routledge, 2000, pp. 109-125. 
46. Mutz, D.C., Population-based Survey Experiments, Princeton: Princeton University Press, 2011.

47. Nana, N., 'Expenditure Decentralization and Outcomes: Some Determinant Factors for Success from Cross-country Evidence', in Proceedings of the African Economic Conferences 2008, Paris: Economica, 2009, pp. 381-397.

48. Noy, C., 'Sampling Knowledge: The Hermeneutics of Snowball Sampling in Qualitative Research', 2008, International Journal of Social Research Methodology, vol. 11, no. 4, pp. 327-344.

49. Oates, W.E., 'An Essay on Fiscal Federalism', 1999, Journal of Economic Literature, vol. 37, no. 3, pp. 1120-1149.

50. Oates, W.E., Fiscal Federalism, New York: Harcourt Brace Jovanovich, 1972.

51. Panizza, U., 'On the Determinants of Fiscal Centralization: Theory and Evidence', 1999, Journal of Public Economics, vol. 74, no. 1, pp. 97-139.

52. Pollitt, C. and Bouckaert, G., Public Management Reform: A Comparative Analysis - New Public Management, Governance, and the Neo-Weberian State, New York: Oxford University Press, 2011.

53. Popa, A.E., 'Medici şi pacienţi - Două perspective asupra reformei şi descentralizării din sistemul sanitar (Doctors and Patients - Two Perspectives on Healthcare Reform and Decentralization', 2011, Calitatea Vieții, vol. 22, no. 2, pp. 177-200.

54. Porumbescu, G.A., 'Linking Transparency to Trust in Government and Voice', 2017, The American Review of Public Administration, vol. 47, no. 2, pp. 520-537.

55. Profiroiu, M.C. and Profiroiu, A.G., 'Decentralization Process in Romania', 2006, Transylvanian Review of Administrative Sciences, vol. 16E, Special Issue, pp. 115-123.

56. Profiroiu, M.C. and Szabo, S.R., 'Outsourcing vs Decentralisation: A Comparative Analysis in Central and Eastern Europe', 2016, Eco-Economics Review, vol. 2, no. 2, pp. 3-26.

57. Profiroiu, M.C., Profiroiu, A.G. and Szabo, S.R., 'The Decentralization Process in Romania', in Ruano, J. and Profiroiu, M. (eds.), The Palgrave Handbook of Decentralisation in Europe, Cham: Springer International Publishing, 2017, pp. 353-387.

58. Prud'Homme, R., 'The Dangers of Decentralization', 1995, The World Bank Research Observer, vol. 10, no. 2, pp. 201-220.

59. Ranis, G., 'Vertical and Horizontal Decentralization and Ethnic Diversity in Sub-Saharan Africa', 2012, Yale Economics Department Working Paper No. 108, [Online] available at https://papers.ssrn.com/sol3/papers2.cfm?abstract_id=2144956, accessed on October 28, 2016.

60. Remler, D.K. and Van Ryzin, G.G., Research Methods in Practice: Strategies for Description and Causation, New York: Sage Publications, 2010.

61. Rondinelli, D.A., 'Decentralizing Public Services in Developing Countries: Issues and Opportunities', 1989, The Journal of Social, Political, and Economic Studies, vol. 14, no. 1, pp. 77-98.

62. Rosenblatt, F., Bidegain, G., Monestier, F. and Rodríguez, R.P., 'A Natural Experiment in Political Decentralization: Local Institutions and Citizens' Political Engagement in Uruguay', 2015, Latin American Politics and Society, vol. 57, no. 2, pp. 91-110.

63. Seabright, P., 'Accountability and Decentralisation in Government: An Incomplete Contracts Model', 1996, European Economic Review, vol. 40, no. 1, pp. 61-89. 
64. Sujarwoto, S., 'Political Decentralization and Local Public Services Performance in Indonesia', 2012, Journal of Public Administration and Governance, vol. 2, no. 3, pp. 55-84.

65. Szabo, S., 'Decentralization Developments in Romania and Poland since 1990', in Profiroiu, M.C and Popescu, R.I. (eds.), Proceedings of Administration and Public Management International Conference, Bucharest: Bucharest University of Economic Studies, 2015, pp. 218-224.

66. Tiebout, C.M., 'A Pure Theory of Local Expenditures', 1956, Journal of Political Economy, vol. 64, no. 5, pp. 416-424.

67. Tranchant, J.P., 'Decentralisation, Regional Autonomy and Ethnic Civil Wars: A Dynamic Panel Data Analysis, 1950-2010', 2016, MPRA Paper No. 72750, [Online] available at https://mpra.ub.uni-muenchen.de/72750/1/MPRA_paper_72750.pdf, accessed on October 28, 2016.

68. Tranchant, J.P., 'Does Fiscal Decentralization Dampen All Ethnic Conflicts? The Heterogeneous Impact of Fiscal Decentralization on Local Minorities and Local Majorities', 2010, MPRA Paper No. 22776, [Online] available at https://mpra.ub.uni-muenchen. de/22776/1/MPRA_paper_22776.pdf, accessed on October 28, 2016.

69. Wenzel, M., 'Motivation or Rationalisation? Causal Relations between Ethics, Norms and Tax Compliance', 2005, Journal of Economic Psychology, vol. 26, no. 4, pp. 491-508.

70. Wibbels, E., 'Madison in Baghdad?: Decentralization and Federalism in Comparative Politics', 2006, Annual Review of Political Science, vol. 9, pp. 165-188. 


\section{Annex 1}

The context of the survey and the question (translated from Romanian)

Please analyze the following fictitious situation within your city: The main subject of debate during the campaign for the latest mayoral election within your city was related to decentralization, a policy through which the central government transfers the management and required resources for certain public services to the local governments (either county or municipal level). Attached is a paragraph from the latest press release of one of the main candidates for mayor:

\begin{tabular}{cc}
\hline Treatment & Treatment \\
Group 1 (Bucharest) and 3 (Cluj-Napoca) & Group 2 (Bucharest) and 4 (Cluj-Napoca) \\
\hline
\end{tabular}

'I do not consider decentralization to be 'I consider decentralization to be necessary applicable in Romania. The public services in Romania. The public services that are that are currently under the control of the currently controlled by the central governlocal governments should actually be con- ment should actually be coordinated and trolled and financed by the central govern- financed by the local governments. In addiment. In addition, taxes and levies collected tion, the taxes and levies collected from the from the population should be allocated population should not be allocated through through an equalization mechanism to all an equalization mechanism to all regions. regions. Finally, I believe that the central Finally, I believe that the central governgovernment should monitor and control the ment should not have the right to control local budgets.' the local budgets.'

Q1: Based on the information you read before, to what extent do you agree that the following public services should be controlled and financed by the local governments within your city and not by the central government? 